\title{
各種レーザーの骨芽細胞及び象牙芽細胞に及ぼす影響 Laser Effect on Osteoblast and Odontblast
}

\author{
山田恵子 \\ 東北大学歯学部小览歯科学講座 \\ 干980-77 仙台市青葉区星陵町 4 番 1 号 \\ TEL $022-717-8382$ FAX $022-717-8386$
}

\section{Keiko YAMADA}

Dept. of Pediatric Dentistry. Tohoku University School of Dentistry. 4-1. Seiryomachi. Aobaku Sendai Miyagi 980-77 JAPAN

\section{要 旨}

レーザーの臨床応用範囲は広がる傾向にあるが，その生体に及ぼす作用機序についての解明 はいまだ億測の域を脱していない。レーザーが骨や象牙質等の硬組織形成を促進する作用を有 することについても，動物実験や臨床応用の結果報告が先行し，そのメカ二ズムの探究が一歩 遅れている感がある。そこでレーザーの骨芽細胞，象牙芽細胞に及ばす作用について著者の実 験結果と，関連するこれまでの報告から考察を加えた。その結果，(1)フトレーザーは適当な 照射条件を用いることにより，骨芽細胞の增殖を促進し，かつ硬組織形成を助長する，(2高出 カレーザーは象牙質細胞を賦活化して二次象牙質の形成を促進し，かつ未分化細胞から象牙芽 細胞への分化をも促進し新生象牙質の形成に奇与することが推察された。

キーワード：レーザー，骨芽細胞，象牙芽細胞

\begin{abstract}
The application of laser is increasing in Medicine and dentistry, however, the biological effect of laser is not made clear yet. The effect of laser on accerelation of hard tissue formation was demonstrated with animal experiments and clinical researchs, but the fundamental research relating to the mechanism is still unclear. In the present paper, the biological effect of laser to osteoblasts as well as to odontblasts is considered from author's research and other reports. The conclusions are as follows. (1) Soft laser accerelates a proliferation as well as a hard tissue formation of asteoblastic cells. (2) High energy laser activates odontblasts to form secondary dentin and enhance defferentiation of indefferent cells to odontblasts.
\end{abstract}

Key words : Laser, Osteoblast, Odontoblast 


\section{はじめに}

医㐘学領域におうるレーザーの忘用は，病態診断，外 科的治療。疾病予防等あら叻る用途に普及してきてお り、さらにその範井は㳂がる傾向にある。レーザー光の 生体への作用は，1）熱，2）生力，3）光，4）電磁 界の 4 つがあると考えら机ており。こ扎らの中でも熱及 び压力は高出力レーザーが、また光，電磁界は低出力 レーザーがそれぞ扸果的で京ると言われている。即 ち, 高出力レーザーは熱により組織在燃枃したり，変性 を生じせしめることより外科的处置に用いられる事が多 い。一方，低出カレーザーについてはその生物学的作用 機序がまだ充分に解明されているとは言えないが，すで に臨床応用が先行して行われ，その結果により次に挙げ るような生体に対する作用があると推測さ机ている。即 5.1) 血流の改善，促准，2)酸素活性の促進，3）細 胞分裂の活発化、4)神経與甥性の抑制，5）血管新生 の促進，6）生体産生物筫の産生促進等である”。これ らの作用機序をさらに詳細に解明するためには、レー ザー照射された細胞の機能の变化について検索する必要 がある。

これまで株化培養細胞に対するレーザーの影響につい ては, 線維芽細胞, 骨芽細胞, 滑膜細胞がその材料之し て用いられ，各種レーザー照射によるそれらの細胞の形 態，增殖能の变化が調べら机報告さ机ている。

ところで歯科領域では蒾の石灰化を促進させる方法は 臨床的にも有用であり，その確実な手段の開発が待たれ るところである。そこで著者らは、レーザーの象牙芽細 胞にたいする作用をin vitro，in vivoの実験により明ら かにしたいと考えた。しかし，象牙芽細胞の株化培盖は 現代では不可能であることにより，石灰化という同様の 機能をもち，しかも株化培莀法が榷立されている骨芽細 胞をin vitro研究の材料とし、またinvivoではうットの 臼萪を用いて実験を行ったところ，若干の知見を得 た2゙、3。そこでその結果上これまでの関連する報告か らレーザーの骨芽細胞, 象牙芽細胞への作用について质 察を加えてみたい。

\section{1、レーザーの骨芽細胞に対する生物学的作 用}

マウスの頭蓋冠由来の株化骨芽細胞( MC 3 T 3 - E 1) を実験材料上して次の項目について調へた。

\section{1）レーザーの細胞增殖に対する影哣}

〈方法〉

a-MEM培地(10\%ウシ胎児血清，1\%ペニシリンース トレプトマイシンーファンギゾン， $5 \mathrm{mM} \beta$-glycero-
表 1 培養日数と細胞数平均値

\begin{tabular}{crrr}
\hline Days & Control & 3min.Lased & 5 min.Lased \\
\hline 1 & $8.5(0.7)$ & $8.6(0.4)$ & $7.8(0.8)$ \\
2 & $21.3(2.1)$ & $18.0(2.2)$ & $17.7(1.9)$ \\
3 & $27.7(3.6)$ & $31.3(2.7)$ & $26.9(4.4)$ \\
4 & $59.0(5.7)$ & $64.7(1.3)$ & $63.3(9.8)$ \\
5 & $76.7(9.9)$ & $70.0(6.5)$ & $70.7(4.2)$ \\
6 & $113.3(26.2)$ & $103.0(21.3)$ & $106.3(12.0)$ \\
\hline
\end{tabular}

(S.D)

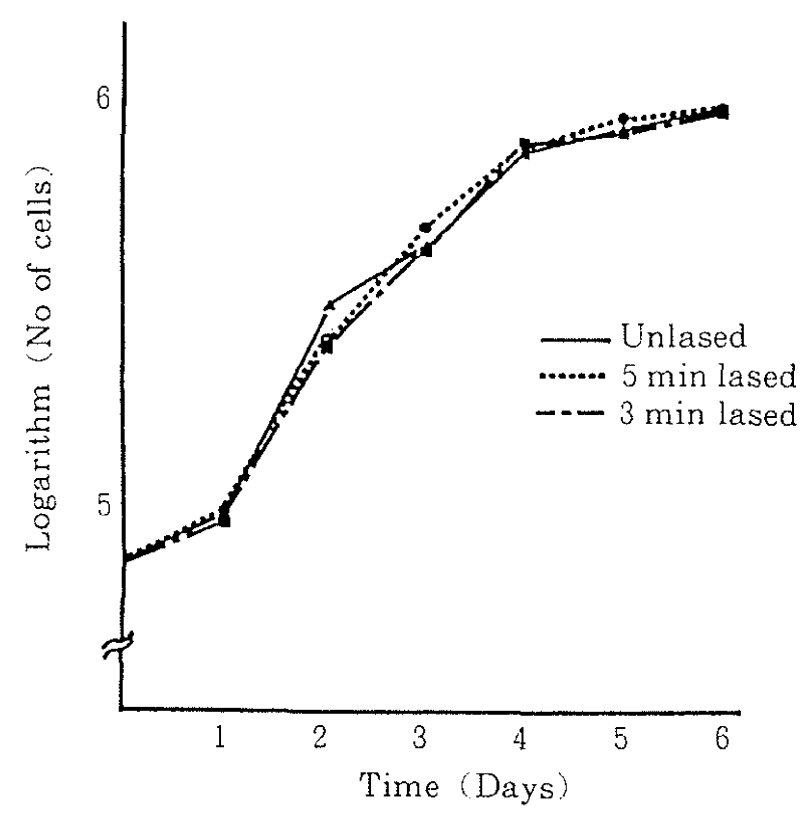

図 1 培姫日数による細胞数の变化

phosphate去含吉) $1.8 \mathrm{~m} \ell$ 入りのplastic dish ( $\phi 35$ min) にMC $3 \mathrm{~T} 3-\mathrm{E} 1$ を $5 \times 10^{4}$ 個播種して, $37^{\circ} \mathrm{CO}$ Oncubator $\left(5 \% \mathrm{CO}_{2}\right)$ 内で $2 \sim 3$ 時間培養後, 細胞が dishの底面に付着したの確認後 dishの底面方向上り He-Neレーザー (World Wide社製，波長632.8nm. 出力 $6 \mathrm{~mW}$ を 3 分間あるいは 5 分間照射した。その後 各dishを3 個ずつincubatorより取り出して培地除去及 び、PBS洗浄した琈0.1\%tripsin処理して遠心分離にか け、血球数测定板を用いて光影下で細胞数老测定した。 同様の測定を6日間繰り返し細胞增殖曲線を得た。培地 は3 日間敏に新鮮培地上交換した。な㧍，対照は同様に plastic dishに細胞を播種して、レーザーを照射せずに 培養し24時間每に細胞数在測定した。

〈結果及び考察〉

培穆時間に対する細胞数の变化を表 1 , 細胞数の常用 対数の変化を図1に示寸。 He-Neレーザ一老照射した 細胞では，いずれの照射時間においても非照射細胞上の 間にその增殖の様相に顕著な差がみられず，今回用いた 
表 2 骨芽細胞に及ぼすレーザーの作用

\begin{tabular}{|c|c|c|c|c|c|c|}
\hline 発表年 & ：筆頭著耆 & 細胞の種類 & レーザー機種(波長) & 出力 (エネルギー密度) & 照射条件 & 作 用 \\
\hline \multirow[t]{6}{*}{1991} & K.YAMADA & $\mathrm{MC} 3 \mathrm{~T}_{3} \cdot \mathrm{E}_{1}$ & $\mathrm{He}-\mathrm{Ne}(632.8 \mathrm{~nm})$ & $6 \mathrm{~mW}\left(0.01 \sim 1.0 \mathrm{~J} / \mathrm{c \mathbb {N }}^{2}\right)$ & 播種 2 日後 & 增殖促進 $(+)$ \\
\hline & & & & & "6日後 & $"(-)$ \\
\hline & & & & & 1日 1 回照射 & 石灰化促進 $( \pm)$ \\
\hline & & & & & " & $\operatorname{ALP}$ 活性 (-) \\
\hline & & & & & 1日1回 4 日連続 & 石灰化促進 $(+)$ \\
\hline & & & & & & $\operatorname{ALP}$ 活性 $(+)$ \\
\hline \multirow[t]{3}{*}{1992} & 高木茂樹 & $\mathrm{MC} 3 \mathrm{~T} 3-\mathrm{E} 1$ & Ga-Hs半導体 $(904 \mathrm{~nm})$ & $2 \mathrm{~mW}\left(0.03 \mathrm{~J} / \mathrm{cm}^{2}\right)$ & 播種 1 日後 1 日 3 回 $F$ & 增殖促進 $(+)$ \\
\hline & & & & & $1,2,4,5$ 回 & 增殖促進 $( \pm)$ \\
\hline & & & & & $\mathrm{A}, \mathrm{B}, \mathrm{C}, \mathrm{D}, \mathrm{E}, \mathrm{G}$ & \\
\hline \multirow[t]{2}{*}{1995} & 山田恵子 & MC3T3-E1 & $\mathrm{He}-\mathrm{Ne}(632.8 \mathrm{~nm})$ & $6 \mathrm{~mW}(0.114,0.187 \mathrm{~J} / \mathrm{cof}$ & )播種 2 時間後 1 回照射 & 増殖促進(土) \\
\hline & & & & & & 石灰化促進 $(+)$ \\
\hline \multirow[t]{3}{*}{1996} & 鈴木浩之 & HU09 & 半導体 $(890 \mathrm{~nm})$ & $0.336 \mathrm{~mW}\left(0.6 \sim 9.0 \mathrm{~J} / \mathrm{cm}^{2}\right.$ & & 增殖促進 $(-)$ \\
\hline & & YT48 & & & & \\
\hline & & 09N2 & & & & ALP活性 $(-)$ \\
\hline
\end{tabular}

レーザーの照射条件（総出力 $1080 \mathrm{~mJ}, 1800 \mathrm{~mJ}$ ）で は，細胞の增殖能に影響を及ぼさないことが明らかに なった。YAMADA"はやはりMC 3 T 3 -E 1 にHe$\mathrm{Ne}$ レーザーを照射してその増殖能の変化をみている が，その結果，細胞の播種培意開始して2 日後即ち細 胞が成長期にある時にレーザーを照射（0.01-1.0J／ $\left.\mathrm{cm}^{2}\right)$ すると，細胞增殖は顕著に促進されるが，培養開始 6 日後即ち安定期の細胞にレーザーを照射してもその增殖 能に変化はみられなかったと報告した。著者の実験では 細胞を播種して2 時間後細胞がdishの底面に付着して 突起を伸ばし始めた時点でレーザーを照射したが，単位 面積当りの細胞数が少ないために，細胞１個当りの照射 エネルギーが非常に低かった可能性が考えられる。高木

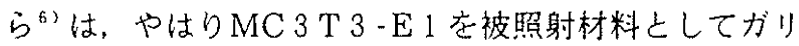
ウム・素半導体レーザー(波長 $904 \mathrm{~nm}$, SEDATELEC 社製)を種々のパルスモードで照射(エネルギー密度0.03 $\left.\mathrm{J} / \mathrm{cm}^{2}\right)$ してその効果をみたところ，Fモードで1日4 分間 3 回照射に於いて細胞增殖能が他に比して有意に促 進された。ガリウム・ヒ素半導体レーザーはパルス变調 が可能であり，その周波数によって $\mathrm{A} \sim \mathrm{G}$ の 7 種類の発 振モードの使用ができる。Fモードは $47.5 \mathrm{~Hz}$ で骨疾患 に有効とされているが，この研究から当レーザーは直接 骨芽細胞に作用してその增殖能を促すことにより，骨を 新生せしめることが推察された。しかし，この研究に用い た照射エネルギー密度 $\left(0.03 \mathrm{~J} / \mathrm{cm}^{2}\right)$ が先のYAMADA の用いたそれと一致しているにもかかわらずFモード以 外の周波数では，増加傾向はみとめたが，有意な差はな かったことに対して，高林6はレーザーの細胞に対する
作用はエネルギー密度のみではなく，その周波数も重要 な因子になっていることを示唆した。鈴木らうはとト由 来の 3 種の骨芽細胞に半導体レーザー(波長 $890 \mathrm{~nm}$, 浜 松ホトニクス社製）を0.6〜 $9 \mathrm{~mJ} / \mathrm{cm}^{2}$ のrangeで照射し DNA合成能の変化を調べたところ，明らかにDNA合 成が促進されたものはなく，むしろ阻害される傾向が認 められたと報告した。しかし、鈴木らの用いた半器体 レーザーはその出力が0. $336 \mathrm{~mW}$ と他のソフトレーザー に比して，非常に低く，その影響も無視できないと思わ れる。

骨芽細胞に対するレーザーの生物学的作用につい てのこれまでの報告を表 2 にまとめた。使用された レーザーは，波長 $632.8 \sim 904 \mathrm{~nm}$, 出力0. $336 \mathrm{~mW} \sim 6$ $\mathrm{mW}$ ，エネルギー密度0.01〜 $9 \mathrm{~J} / \mathrm{cm}$ でいずれも低出力 レーザーが用いられている。また，細胞の増殖能に関す るレーザーの影響については(1)促進した(YAMADA"， 高木ら $\left.{ }^{6)}\right)$ ，(2)抑制した(鈴木らう)，(3)非照射と同じ $\left(Y_{A M A D A}{ }^{2)}\right)$ と，そ机ぞれ巽なる結果を得ている が，マウスの骨芽細胞の增殖を促進させる必要条件とし て挙げるならば，細胞の成長期にエネルギ一密度0.01〜 $1.0 \mathrm{~J} / \mathrm{cm}^{2}$ が適当であると言える。しかし，ヒトの骨膜 由来細胞では逆に増殖が抑制される㑯向がみよめられ たことから，細胞種によりその反応性が異なることも 推察される。他の細胞を用いてレーザーの細胞增殖に関 する影響を調べたものとして，RA滑膜培委細胞（山田 $ら^{7)}$ )，線維芽細胞（J. Rigau et $\mathrm{al}^{82}$ ) 等があるが, いずれも He-Neレーザーを照射したところ，增殖は抑 制されたとしている。いず机にしても低出力レーザーが 
表 3 培䖯期間と沈着カルシウム量 $(\mu \mathrm{g} / \mathrm{dish})$

\begin{tabular}{|c|c|c|c|c|c|c|c|}
\hline & 1 week & & 2 weeks & & 3 weeks & & 4 weeks \\
\hline Control & $7.6(0.93) \square$ & 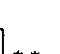 & $11.6(0.22)$ & & $12.2(0.21) \square$ & & $15.6(0.85)$ \\
\hline $3 \mathrm{~min}$. Lased & $8.2(1.22)$ & $\stackrel{* *}{\square}$ & $11.6(0.36)$ & $*$ & $13.1(2.08)$ & $* *$ & $18.2(1.31)$ \\
\hline $5 \mathrm{~min}$. Lased & $14.5(0.14)$ & $u^{*}$ & $14.6(1.11)-$ & & $15.2(0.90)-$ & & $21.9(0.46)-$ \\
\hline
\end{tabular}

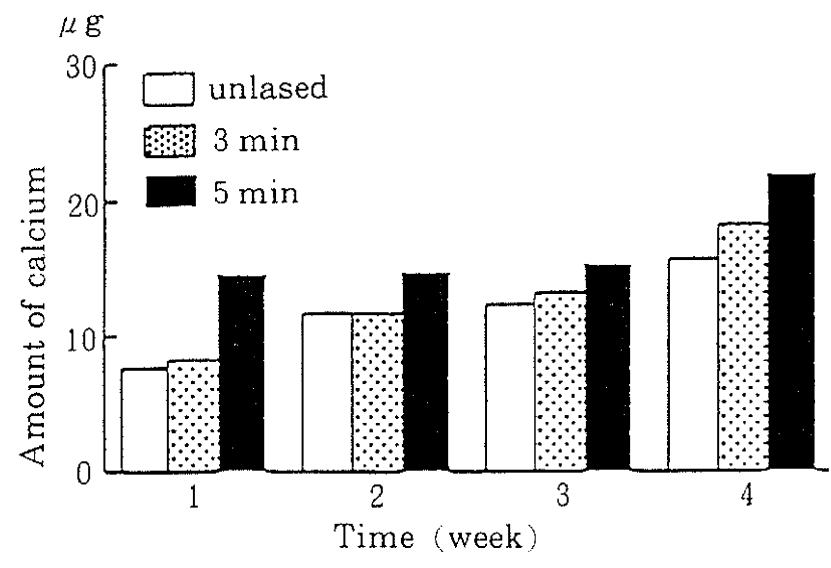

図 2 培期間と沈着カルシウム量（ $\mu \mathrm{g} / \mathrm{dish})$

細胞に直接作用し，その增殖能に影響を与えることは明 らかであると言えるが，照射条件や細胞周期その他の因 子でその影製は微妙に異なり, 結果的に全く逆の所見が 得られている。しかし，低出カレーザーにより，骨芽 細胞の壃殖を促進することが可能であることが示され た。

\section{2）レーザーの硬組織形成に対する影每 \\ 〈方法〉}

1) の実銩上同樣に播種し、レーザー照射したMC 3

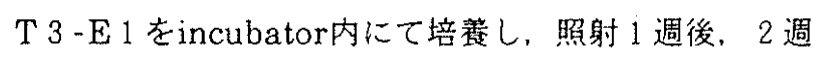
後， 3 週後， 4 週後の細胞内外に沈着したカルシウム嘿 を原子吸光光度計にて测定した。なお，対照はレーザー 照射を除いて全て実験群と同様の処理を行った。

〈結果及び考察〉

各週每の沈着カルシウム量を表 3，図2に示した。5

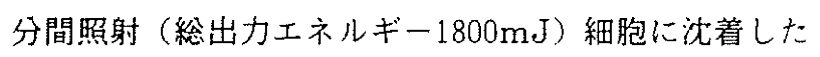
カルシウム量は、いずれの週においても対照群よりも有 意に高い值を示した。

レーザー照射による骨芽細胞の硬組織形成能に対する 影警については，YAMADA"も1日1回ずつ4日間

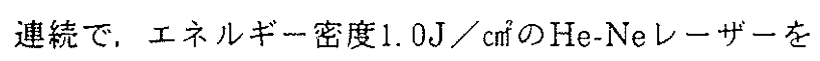
照射した細胞でカルシウム沈着が有意に促進され，同時 にALP活性も上昇していたと報告した。一方, 鈴木 ららはヒト骨肉腫由来細胞に半導体レーザーを10分間以 上照射すると，ALP活性はむしろ抑制されたとしてい
る。しかし，同時に増殖も抑制されており，1細胞の硬 組織形成能への影響は推測できない。著者らの実験結果 では, 非照射細胞之細胞数は变わらないが, 照射細胞の カルシウム沈着量が有意に增加したこよは細胞の機能の 分化にレーザーが直接作用したことを示すものであると 考える。Rigau ${ }^{8}$, Lam $^{9)}$ は上トの線維芽細胞にHe-Ne レーザー, Ga-Asレーザーを照射すると, 細胞の増殖 は促進されないが、コラーゲンの新生が促進されること を報告した。この報告もレーザーが細胞の機能を䟼活化 したことを裏付けるものと考えられる。

3）レーザーの細胞内カルシウムイオン濃度に与える 影響について

〈万法〉

径25mm Dlastic dishに滅菌ガラス板を固きその上か らMC 3 T $3-\mathrm{E} 1$ を $5 \times 10^{4}$ 個播種して 2 時間, 4 日, 1 週 間培㖉後に培地を除去，PBSで洗浄した後10 $\mu$ MFura$2 \mathrm{AM}, 0.1 \%$ アルブミンを含む $5 \mathrm{mM} \mathrm{KCl} \mathrm{Hepes}$ 液を加えて 1 時間, incubatorに放䈯後, 再び取り出し て細胞内カルウシムイオン測定装固のキュベットにガラ ス板を設定して $2 \mathrm{~m} \ell$ の $5 \mathrm{mM} \mathrm{KC \ell Hepes}$ 溶液をキュ ベット内に満たした。base lineとしてこのままの状態 で340nm，380nmの蛍光強度此を 3 分間测定した後。 レーザー(He-Neレーザー，Ga-Al-Asレーザー)をそれ ぞれ3分間あるいは 5 分間照射し，その直後再び測定 し、レーザーによる細胞内カルウシムイオン濃度の变化 を算出した。

\section{〈結果及び考察〉}

表 4 にそれぞれの照射条件における照射前後の监光強 度及び变化量（照射前後の営光強度比の差／照射前の営 光強度比）を示した。 5 分間照射群においてはHe-Ne レーザーのほうが細胞内カルウシムイオン垬度を上昇さ せる傾向を示したが, 10分間照射群では両レーザーとも 同様の上昇量を示した。また、レーザー照射の時期につ いては播種4日，1週間後で高い变化量を示した。即 ち，低出カレーザーは細胞内のカルシウムイオン濃度を 高める作用があることが示㖟された。

細胞内カルウシムが硬組織形成細胞で果たす役割とし 
表 4 骨芽細胞内カルシウムイオンの変化

\begin{tabular}{c|cc|cc}
\hline & \multicolumn{2}{|c|}{ He-Ne Laser } & \multicolumn{2}{c}{ Ga-Al-As Laser } \\
\hline Culture Duration & 5 minutes & 10 minutes & 5 minutes & 10 minutes \\
\hline 2 hours before irradiation & $0.48(0.005)$ & $0.46(0.014)$ & $0.47(0.009)$ & $0.49(0.016)$ \\
after irradiation & $0.57(0.024)$ & $0.53(0.022)$ & $0.52(0.016)$ & $0.55(0.017)$ \\
ratio & 0.19 & 0.15 & 0.11 & 0.12 \\
\hline 4 days before irradiation & $0.61(0.017)$ & $0.62(0.005)$ & $0.67(0.010)$ & $0.63(0.015)$ \\
after irradiation & $0.71(0.034)$ & $0.74(0.005)$ & $0.73(0.050)$ & $0.76(0.005)$ \\
ratio & 0.16 & 0.19 & 0.09 & 0.20 \\
\hline 7 days before irradiation & $0.64(0.033)$ & $0.61(0.015)$ & $0.66(0.005)$ & $0.61(0.015)$ \\
after irradiation & $0.73(0.014)$ & $0.73(0.005)$ & $0.72(0.012)$ & $0.74(0.010)$ \\
ratio & 0.14 & 0.19 & 0.09 & 0.21 \\
\hline
\end{tabular}

$\mathrm{N}=3$, Mean (S.D.)

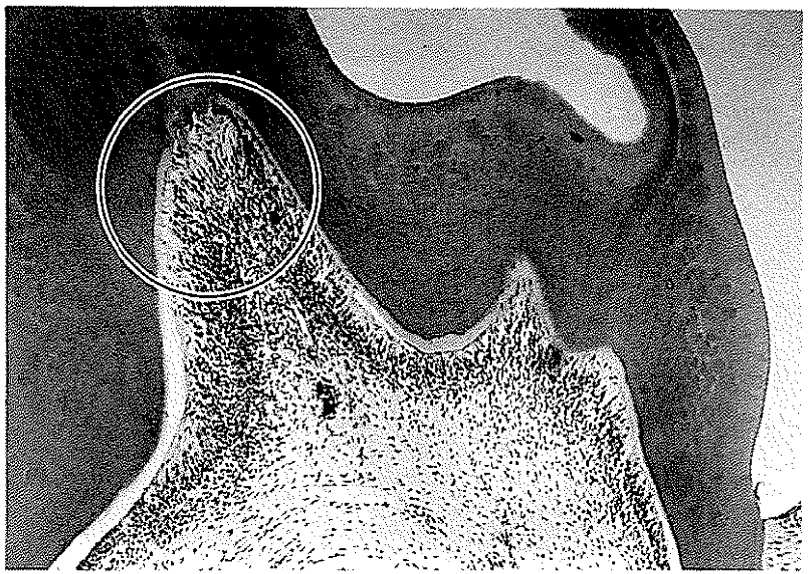

図 3 Nd:YAGレーザー（10J）照射 3 日後の蒾榷

(HE染色、100倍)

○領域に細胞配列の乱れがみられる

て基質の石灭化之細胞内情報伝達を担うシグナルとして の 2 つが考えられている。骨芽細胞のカルシウムチャネ ルはPTHなどのホルモンによりその存在が報告されて いる。当実験ではレーザー照射が骨芽細胞内のカルシウ ムイオン濃度を上昇させたが，その作用機序としては レーザーの刺激により，(1)カルシウムチャネルが開き細 胞外からカルシウムイオンが入りこんだ，(2)小胞体に蓄 えられていたカルシウムイオンが細胞内に放出された等 が推測される。いずれにしてもレーザーが細胞内カルシ ウムイオン浱度に変化をもたらし，石灰化の機能が促進 される可能性が考えられる。

\section{2.レーザーの象牙翼形成促進作用について} 大久保ら ${ }^{01}$ はラットの歯にNd：YAGレーザーを， またNagasawaら"1はやはりラットの畨にルビーレー ザーを照射したところ，㐘喵内に著しい二次象牙質の形 成を認めたよ報告して以来レーザーの象牙芽細胞に対す

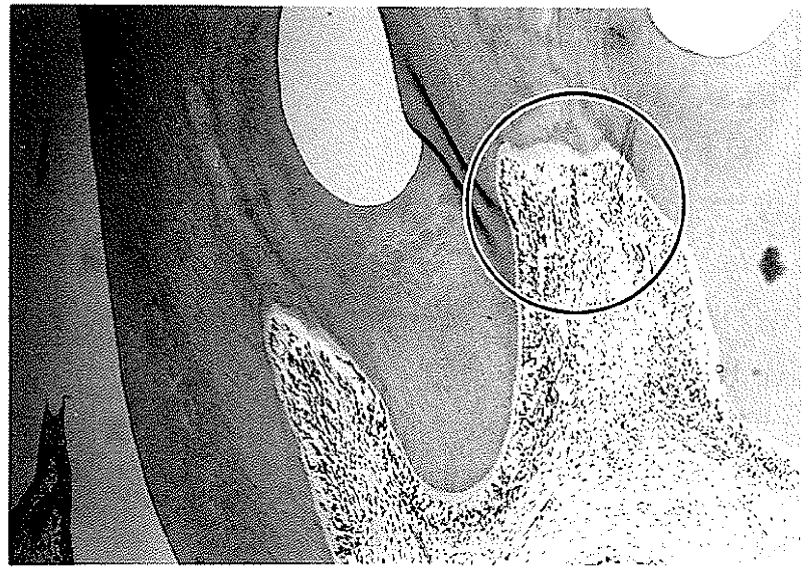

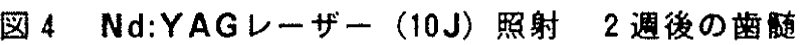
(HE染色、100倍)

○領域に二次象牙留形成

る生物学的作用に関する関心が高まった。前述した通り 象牙芽細胞の株化は確立されていないために，in vitro の奏験としては㐘胚を組織培養してレーザーを照射する 系が，またin vivoでは動物の㐘にレーザーを照射し柬 骾の変化を顕微鏡的に観察したものがこれまで報告され

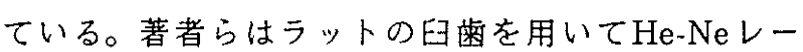
ザー, Nd：YAGレーザーの歯髄に与える影䈉を観察し た。

\section{〈方法〉}

4 週齢のWister系ラットの上額臼菌を被験㐘とし た。ネンブタールによる注入麻酔下で被駼歯の咬頭を削 除して残存象牙質の厚さを可及的に薄くして 2 種類の レーザーを次の条件にて照射した後，3日，1，2 週後 の粎骵を光学顕微鏡下で観察した。

〈照射条件〉

(1) He-Neレーザー（波長632. $8 \mathrm{~nm}$, 出力 $6 \mathrm{~mW}$ )を 5 分間照射 
表 5 レーザーの菊髄に及ぼす影響

\begin{tabular}{|c|c|c|c|c|c|}
\hline 発表年 & 筆頭著者 & 実験動物 & $\begin{array}{c}\text { レーザー機種 } \\
\text { (波 長) }\end{array}$ & 出力(エネルギー密度) & 響 \\
\hline 1982 & 大久保勉 & ラット & $\begin{array}{l}\text { 音波Qスイッチ } \mathrm{Nd}: \mathrm{YAG} \\
(1064 \mathrm{~nm})\end{array}$ & $10 \mathrm{~W}\left(32 \sim 96 \mathrm{~J} / \mathrm{cm}^{2}\right)$ & $\begin{array}{l}\text { 全ての照射部に二次象牙質形成 } \\
\text { 重度の迷䠝伤害あり }(96 \mathrm{~J} / \mathrm{cm})\end{array}$ \\
\hline 1984 & ANAGASAWA & ラット & $\begin{array}{c}\mathrm{Ar} \\
(488 \mathrm{~nm})\end{array}$ & $2.5,7.5,10 \mathrm{~J}$ & 1ヶ月〜3ヶ月㣪に二次象牙質形成 \\
\hline 1987 & 中村幸生 & ラット & $\begin{array}{l}\text { 連続波 Nd:YAG } \\
(1064 \mathrm{~nm})\end{array}$ & $10 \mathrm{~W}\left(31 \sim 52 \mathrm{~J} / \mathrm{cm}^{2}\right)$ & 象牙芽细胞が新生, 二次象牙質形成 \\
\hline 1987 & J.MELCER & ニホンザル & $\begin{array}{c}\mathrm{CO}_{2} \\
(10.6 \mu \mathrm{m}) \\
\end{array}$ & $10^{3} \sim 25 \times 10^{3} \mathrm{~J} / \mathrm{cmi}^{2}$ & 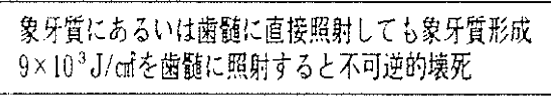 \\
\hline 1990 & 王紅虹 & イヌ & $\begin{array}{l}\text { 連続波 Nd:YAG } \\
(1064 \mathrm{~nm})\end{array}$ & $1.5 .10 \mathrm{~W}\left(114 \sim 229 \mathrm{~J} / \mathrm{cm}^{2}\right)$ & IW, 5Wで二次象牙質形成 \\
\hline 1992 & 海老原新 & イヌ & $\begin{array}{l}\text { 連続波 Nd:YAG } \\
(1064 \mathrm{~nm})\end{array}$ & $305 \sim 1524 \mathrm{~J} / \mathrm{cm}^{2}$ & 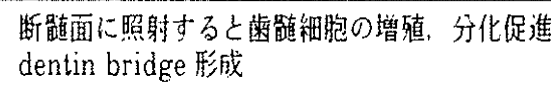 \\
\hline
\end{tabular}

(2)連続波Nd：YAGレーザーを $5 \mathrm{~J}$ ( $5 \mathrm{~W}, 1$ 秒間) あるいは10J (10W，1 秒間) 照射

〈結果及び考察〉

(1)He-Neレーザー：レーザー照射部寘下の歯髄を観 察したところ，照射 3 日，1週，2週後のいずれにおい ても非照射歯髄細胞之比して量いが認められず，迷髄の 石灰化もみとめなかった。

(2)連続波Nd：YAGレーザー：5J照射群の㐘髄はい ずれの観察時期においても対照と特に異なる所見は認め なかったが，10J照射雨蒾随では 3 日後に象牙芽細胞の 配列の乱れや細胞侵潤がみられ(図 3 )，さらに2 週間後 では二次象牙筫が形成されているものもあった(図4)。

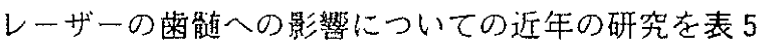

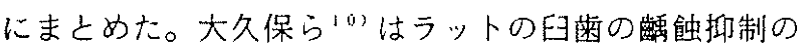
目的で超晋波Qスイッチ $\mathrm{Nd}$ ：YAGレーザ一を照射し て200日間の䨤䯣の経過を観察した結果，照射雨の全て

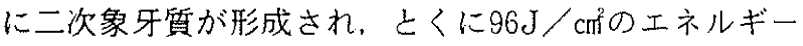
では根部歯梿にまで石灭化を呈しているものがあったと 報告した。Nagasawaら'”はラットの日雨にアルゴン レーザーを照射したところ $3 \mathrm{~J}$ 照射蒾では3ヶ月以内

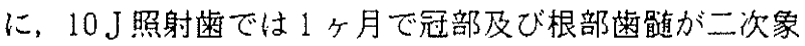
牙質で満たされたと述べている。さらに中村123はラッ

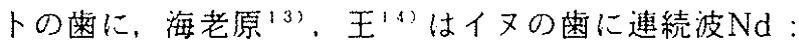
YAGレーザーを照射して歯骾の反応を観察している が，いずれも照射直後には象牙芽細胞に軽度の第害をみ とめたが，時間の経過と共に治癒し，その後象牙芽細胞 が新生，增殖して多鹠の二次象牙質形成がなされたと述 ベた。一方，Melcer (5)はサルとイヌの象牙質と歯髄に $\mathrm{CO}_{2}$ レーザーを照射したところ，象牙芽細胞の治瘾と新 たな細胞の出現による象牙質の形成がみられたと報告した。 上述の報告では，二次象牙質形成を促進するレーザー
の機種はアルゴンレーザー，Nd：YAGレーザー（超 音波 $\mathrm{Q}$ スイッチ，連続波）， $\mathrm{CO}_{2}$ レーザ一と高出力レー ザーが用いられていた。著者はラットの象牙質にHe- $\mathrm{Ne}$ レーザーを照射したが，柬髄への影響は認めなかった。 しかし，直接露出歯髄へ適用して象牙質の形成を促す目 的で用いるレーザーの機種としては，He-Neレーザー も有効と思われる。また，実験動物や照射部位はそれぞ 机の報告によって異なり，用いられたエネルギー密度も 多岐にわたっていることから，象牙質形成を促す適当な 照射エネルギー密度を設定することは困難である。

ここで、レーザーは象牙芽細胞にどのような作用をし て象牙質形成を促進させるのかについて推諭してみると

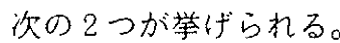

(1)エナメル質あるいは象牙質にある程度の高出力レー ザーを照射すると，その熱により象牙細管中の組織液の 蒸散やイオン交換シスデムの变化等が生じることにより 象牙芽細胞に刺激の情報が伝達されて，その刺激に対す る防御目的で細胞か賦活化されて二次象牙質の形成が促 進される。

(2)菌髄に近接した象牙筫あるいは幽髄に直接強いエネ ルギーのレーザーが照射されると，その熱により象牙芽 細胞は一部損賃されるがレーザーの殺菌作用により感染 等の二次的な侵㜞も予防されることにより，生活力が旺 盛な橉で岕れば治漂機転が生じ，周囲の多量の線維茅細 胞や未分化細胞から舜牙芽細胞が分化し, 新生象牙筫 (dentin bridge) を形成する。

一般にヒトの二次象牙質は, 踩蝕, 咬合力等に上る長 期にわたる持続的な弱い刺激により形成される上言われ ているが，高出力レーザーはその刺激量がかなりと大き いと思われる。しかし，その刺激は一過性の極めて短い 時間であるために，象牙芽細胞は不可逆的な变性をする 
ことなく，むしろ賦活されるだろうと思われる。

\section{おわりに}

レーザーの骨手細胞，象牙芽細胞に対する作用につい て，著者の研焭結果之これまでの関連報告を紹介し考察 を加えてみたところ，次の様にまとめることができる。

1. 骨芽細胞を賦活化するにはソフトレーザーが有効 であるが，なかでも適当な照射条件下でのHe-Neレー ザーは細胞の増殖能の促進, 硬組織形成促進に適した機 種であると思わ扎た。

2 、象牙芽細胞を賦活化して象牙質の形成を促進する 目的に適用するレーザーは，高出力レーザーが有効であ ると思われるが，歯䯙に直接照射して新生象牙質を形成 させるにはソフトレーザ一の使用も推奨される。

臨床的には，骨折部位の治癒を促進するためのレー ザー照射はすでに報告されており，その良好な成續をあ げている。また，象牙筫の形成についても断㖪面への レーザー照射，䶚蝕下の二次象牙質の形成促進による間 接楒跹法等に大いに応用価值があると思われる。今後, 良好な臨休成績の報告が数多くなされ、レーザーが米科 臨床の場にさらに活躍することを期待するものである。

\section{文 献}

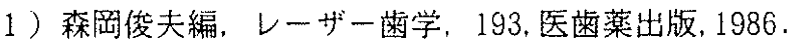

2) Keiko YAMADA, Kikuo KAMIYAMA et al. : He-Ne Laser Effect on Hard Tissue Formation in Osteoblastic Cells:日本レーザー匊学会 誌 $5: 35-40,1994$.

3）神山紀久男：レーザーによる米䯣細胞賦活化と象牙 質形成促進について，文部省科研費報告整，1994。

4) Kunio YAMADA : Biological Effect of Low Power Laser Irradiation on Clonal Osteoblastic Cells (MC 3 T 3 -E 1) , 日整会誌 65：787-799, 1991.

5）鈴木浩之，田中英俊、橋本賢二：培養骨芽細胞に対 する半䜌体レーザー照射の影響に関する実験的研 究，日本レーザー迷学会誌 5:41-46,1994.

6 ）高木茂樹，中川敏浩, 藤山正之, 山本茂久：ソフト レーザーの効果に関する基礎的研究，日本レーザー 医学会誌：13,21-26, 1992 .

7) 山田邦男 他：低出カレー斗一照射がRA滑膜培盖 細胞のDNA合成能に及ぼす影響、日本レーザー医 学会誌, $4: 3-10,1990$.

8 ) J. Rigau, M. A. Trellas, R. G. Colderhead and E. Mayayo : Changes in Fibroblast prolifera- tion and Metabolism following in vitro HeliumNeon Laser Irradiation:Laser Therapy 3:2533, 1991.

9 ) Thomas S. Lam, et al. : Laser Stimulation of Collagen Synthesis in Human Skin Fibroblast Cultures. Lasers in the Life Science 1 : 61-77. 1986.

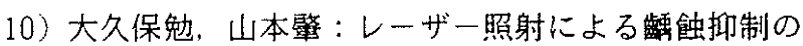
実験的研究，東北歯誌 $1: 19-25,1982$.

11) Akinori NAGASAWA : Experimental Study on the Histological Changes in Pulp of Rat with Exposure to Argon Laser, 日本レーザ一医学会 誌, 4 : 269-270, 1984 .

12）中村幸生：連続波 $\mathrm{Nd}$ ：YAGレーザー照射による ラット生活迷㭪道の病理組織学的变化, 口腔病理誌, $54: 81-97,1987$.

13）海老原新，関根義朗，武田敦志, 須田英明： $\mathrm{Nd}$ : YAG レーザーの直接覆梿法への応用に関する研 究, 日迷保誌, $35: 876-886,1992$.

14）王紅虹：イヌ前蒾象牙質窝洞へのNd：YAGレー ザ一照射による蔽髄の病理組織学的変化について， 日迷保誌，33：1643-1658, 1990.

15) J. Melcer, M. T. Chaumette and F. Melcer : Dental Pulp Exposed to the $\mathrm{CO}_{2}$ Laser Beam, Lasers in Surgery and Medicine $7: 347-352$, 1987. 